\title{
Comment: The Gift that Keeps on Giving? Consequences of Affirmative Action Gerrymandering
}

\section{Charles S. Bullock, III, University of Georgia}

Various interpretations are being given to the 1994 elections. Aside from President Clinton's unpopularity and an expanding Republican base, some Republicans running in the U.S. House and state legislative contests benefitted from redistricting decisions made two or three years earlier. A number of observers agree with an unsigned observation in The New Republic that "The racial gerrymandering of 1990 was key to this year's Republican victory" (Anonymous 1994, 12). At a minimum, the Faustian agreement between Republicans and black Democrats contributed to the continuing implosion of the Democratic party in the South.

In contrast to the 1980 s GOP claim of redistricting disadvantages cited by Aistrup (1995), today's affirmative action gerrymanders provided shortterm payoffs for both partners. In the long-term, however, one partner may pay heavy costs while the other reaps great rewards.

African-American legislators are often the most liberal while Republicans in most assemblies are among the most conservative. Republicans win with virtually no support from blacks while legislative Black Caucuses usually include no Republicans. Rarely do these diametrically opposed groups make common cause as they did in drawing legislative districts. It became rational for the ideological opponents to unite and for black Democrats to betray their white fellow partisans because if additional districts likely to elect members of the allied groups were to be drawn, they would come from seats presently occupied by white Democrats. The strange bedfellows united in some states for redistricting in the 1970s (Hill 1994) and 1980s (Bullock 1983; Holmes 1984; Ehrenhalt 1983) but the coalitions became more prevalent as changes necessitated by the 1990 census were implemented.

By bleaching some districts, sufficient numbers of African Americans could be extracted to create majority minority districts. These districts were likely to elect blacks while the adjacent whitened districts offered

Charles S. Bullock, III, is the Richard B. Russell Professor of Political Science at The University of Georgia. 
Republicans improved prospects. If plans worked as intended, more southern blacks and Republicans would be sent to legislative bodies.

The goals of the GOP-black coalition were abetted by the U.S. Department of Justice (DOJ). All southern states except for Arkansas and Tennessee must obtain approval from Justice or from the Federal District Court of the District of Columbia before implementing redistricting plans. ${ }^{1}$ DOJ interpreted Section 2 of the Voting Rights Act, as amended in 1982, to require that majority minority districts be drawn whenever possible so that when states submitted their handiwork of the 1990s for preclearance, the Justice Department did not allow concerns about compactness and respect for political boundaries to impede the creation of majority minority districts. ${ }^{2}$ DOJ relied on representatives of the minority community and Republicans to determine whether additional majority minority districts could be drawn. Especially at the congressional level, failure to maximize the number of minority districts resulted in the rejection of reapportionment plans.

Two types of personnel serve in the Voting Rights Section of the Justice Department-professional civil servants and political appointees. The professionals seem to have accepted the premise that the number of minority districts should be maximized in order to promote the election of minority officials. Republican appointees in the upper strata of the Bush Justice Department upheld recommendations from the professionals and rejected plans that failed to maximize majority minority districts.

The politicization of DOJ Republican appointees during the early 1980s was suggested by Bullock (1983) but vehemently denied by Brace, Grofman and Handley (1987). Following the 1990 round of districting, evidence on the partisan motivations of appointees at Justice has emerged. John Dunne, the assistant attorney general for civil rights and a former New York Republican legislator, has testified that,

You know, I can't tell you that I was sort of like a monk hidden away in a monastery with only the most pure of intentions. I am a Republican. I was part of a Republican administration. And to tell you that at no moment during the course of my, the discharge of my responsibilities, was I totally immune or insensitive to political considerations, I don't think would justify anybody's belief $(1994,22)$.

\section{Consequences}

African American candidates fared well in the first congressional elections following the redistricting of the 1990s. They won all of the new majority black congressional seats save one in Philadelphia where the white 
incumbent held on to a $52 \%$ black district. African-Americans in Congress increased by 13, all but one of whom came from the South.

Along with the new black members came nine additional elections following the redistricting of the 1990s. The link between the election of blacks and Republicans was clearest in Georgia where two additional African-Americans and three additional Republicans won. Republicans won districts in which the black populations had been reduced by as much as 21 percentage points in order to create majority black districts nearby. Affirmative action gerrymanders may have also contributed to the election of blacks and Republicans in Alabama and Florida. Republican gains in Arkansas, South Carolina and Texas did not come in districts affected by the crafting of minority districts. ${ }^{3}$

At the state legislative level, in 1992, African-Americans added 31 seats in southern lower chambers and 20 in Senates. Republican gains were 45 in Houses and 17 in Senates.

In 1994, African-American gains stagnated while Republicans soared to new heights. Blacks won no additional southern districts with their only gain being J.C. Watts (OK), a Republican from a district only seven percent African-American. National trends such as antipathy toward President Clinton and rising Republicanism played a part in making it difficult to determine what share of the explanation for GOP successes is uniquely attributable to redistricting. Despite the uncertainty, we know that districting was not the sole factor in the 16 seats Republicans added in the South.

Republican pick ups most clearly linked to affirmative action gerrymandering are the three seats in Georgia, the four in North Carolina, and the one in Mississippi. ${ }^{4}$ The margins by which Republicans won some of these districts would not have been offset even if blacks had not been removed from the districts. On the other hand, more African-Americans in these districts and commensurate stronger Democratic showings in 1992 might have dissuaded the victorious Republicans from running so that the Democrats who lost would have faced weaker challengers-opponents less adept as fund raisers and campaigners. If the Democratic legislatures had not been at the mercy of DOJ when drawing districts, they might have fashioned more safe Democratic seats.

As in Congress, Republican state legislative gains in 1994 far outstripped those of blacks. For the first time in more than a century, Republicans won majorities in the Florida Senate and the North Carolina House and took a plurality in the South Carolina House. In Georgia, one additional black was elected to each chamber while Republicans added fourteen House and three Senate seats. The partisan impact of redistricting may have well been heightened by the elimination of multimember districts which Jewell 
and Breaux (1995) and Bullock and Gaddie (1993) have concluded advantaged Republicans.

Joseph Aistrup (1995) sees little evidence that redistricting helped Republicans in the 1970 s and 1980 s. While Aistrup may be correct, ${ }^{5}$ his finding may not be generalizable to the 1990s. As noted above, not until this decade did Justice force states to adopt plans intended to maximize the numbers of majority black congressional districts and increase, even if not maximizing, majority minority state legislative districts. ${ }^{6}$

One basis for assessing consequences of the districting plans for two groups that often worked for their adoption is to see the degree to which each won state legislative districts that it might be expected to win. To what extent have African-Americans won majority black districts? Have Republicans been elected from the districts in which their party is strong? To answer these questions for all southern states is beyond the scope of this effort. The examination, therefore, is restricted to Georgia where we have especially good data on what the GOP saw as targets of opportunity.

In 1992 African-Americans were elected from $75 \%$ of the Senate and $71 \%$ of House districts that were majority black in population. In 1994, that figure crept up to $74 \%$ in the House while remaining unchanged in the Senate. The 1992 elections saw Republicans win $55 \%$ of the House and 52\% of the Senate districts in which the party estimated that their share of the vote should exceed 50\%.7 In 1994, Republicans won an additional 12 House and 5 Senate seats in which previous statewide GOP candidates have averaged a majority of the vote bringing the percentages of likely GOP districts held by Republicans up to 72 and 68 for the upper and lower chambers, respectively.

In districts in which African-Americans were most concentrated, blacks won five of six Senate districts with a population at least $65 \%$ black, the threshold that many, including the primary force behind the Georgia plan, thought necessary (Wilde, 1994). In 1992 blacks carried all but two of 23 House districts that were $65 \%$ black or higher in population and captured one of the two elusive seats two years later. Republicans took 11 of 15 Senate seats in 1992 where the GOP share of the vote was projected to be at least $55 \%$ and added a twelfth seat in 1994. House Republicans won 38 of 52 seats with projected vote shares above 55 in 1992 and gained another eight in 1994.

\section{Conclusions}

Unless the trickle of African-Americans moving into the GOP swells, the consequences of the 1990 s redistricting bode ill for black policy interests 
on multiple dimensions. The growing number of Republican legislators have no election-based incentive to respond to black concerns since they receive no black votes (c.f. Bullock 1995). Fewer of the surviving white Democrats will have enough black constituents to make viable the biracial coalitions that have held Republican ambitions in check and promoted attentiveness to black policy demands.

While fewer whites of both parties will have a black electorate to court, the larger cohort of African-American legislators may need to weigh white policy preferences. The newly created majority-black districts do not have overwhelming numbers of African-Americans and some of the older districts have lost black population to new majority-minority districts. In contests in which all major candidates are black, the white vote can be determinative as it was in 1986 in Georgia's Fifth congressional district contest between John Lewis and Julian Bond or in North Carolina's 12th in 1992. In these kinds of contests, the more moderate African American is likely to triumph with white support even if most blacks prefer the more liberal candidate (Canon, Schousen and Seller 1993).

In state legislatures and Congress where Republicans are the majority, the Black Caucuses have become minorities within a minority. Particularly in the southern legislatures, where GOP majorities are the narrowest, even slight modifications to create additional white Democratic districts by apportioning out black populations rather than concentrating them might have enabled Democrats to cling to power. When Democrats are the majority, African-Americans have the potential to be committee leaders and major players in shaping legislative agendas. When Democrats are the minority party, black legislators have little leverage.

Upon signing the Civil Rights Act of 1964, President Lyndon Johnson speculated that he might have delivered the South to the GOP for the next generation. His fear was premature. If Republicans become the region's majority party, it will be at least partially the result of the enforcement of the Voting Rights Act-where Johnson was again the moving force-by a Republican Justice Department that took the districting aspirations of the black political elite and gave new meaning to the old curse: "May your wishes come true."

\section{NOTES}

${ }^{1}$ No states availed themselves of the option of seeking approval from the federal district court in the District of Columbia. In the past, jurisdictions that turned to the court for relief had so rarely prevailed that by the early 1990 s these appeals were thought to be futile. 
${ }^{2}$ John Dunne (1994), the Assistant Attorney General for Civil Rights during the early 1990s, acknowledged that even districts that he thought oddly shaped were acceptable to Justice if they were likely to elect minorities. Similar odd shapes characterized by fingers and land bridges were deemed objectionable if thought to dilute minority influence.

${ }^{3}$ Hill's (1994) model indicates that the Georgia and Alabama districts won by Republicans were the product of racial gerrymandering.

${ }^{4} \mathrm{Hill}$ (1994) predicted that two of the Georgia districts and one of the North Carolina districts that went Republican in 1994 would change party that year due to affirmative action redistricting.

${ }^{5}$ Aistrup's analysis excludes uncontested elections. Packing the minority Republicans into districts that Democrats did not contest would leave a greater number of seats for Democrats, some of which Republicans would eschew. Aistrup doubts that the elimination of uncontested districts influenced his findings-but it may have-which could account for Aistrup's conclusions being at variance with those of Bullock and Gaddie (1993) and Jewell and Breaux (1995) at least in the context of the switch from multi-member to single-member state legislative seats.

${ }^{6}$ Evidence that the Justice Department was pressing for the adoption of black maximization plans comes from the testimony of two DOJ attorneys, John Dunne (1994) and Thomas Armstrong (1994).

${ }^{7}$ For the last four elections, Georgia Republicans have estimated the share of the vote that they believe their party can obtain in legislative districts based on the past performance of Republicans running statewide. Contests used for these regression-based estimates include the latest presidential, gubernatorial and senatorial elections along with one or more down-ticket offices. The estimated share of the vote is referred to as the ORVIS score. These scores are discussed further in Bullock and Shafer (1993) and have been developed in several states.

\section{REFERENCES}

Aistrup, Joseph A. 1995. Southern Republican Subnational Advancement: The Redistricting Explanation. American Review of Politics 16:15-32.

Anonymous. 1994. "Election Notebook," The New Republic (November 28):8-12.

Armstrong, Thomas. 1994. Testimony in Georgia v. Reno, CV 194-08, S.D. GA (Augusta Division).

Brace, Kimball, Bernard Grofman and Lisa Handley. 1987. Does Redistricting Aimed to Help Blacks Necessarily Help Republicans? Journal of Politics 49:169-185.

Bullock, Charles S., III. 1983. The Effects of Redistricting on Black Representation in Southern State Legislatures. Presented at the annual meeting of the American Political Science Association, Chicago, September 1-4.

. 1995. The Impact of Changing the Racial Composition of Congressional Districts on Legislators' Roll Call Behavior. American Politics Quarterly 23:141158. 
Bullock, Charles S., III and Ronald Keith Gaddie. 1993. Changing from Multimember to Single-Member Districts: Partisan, Racial and Gender Consequences. State and Local Government Review 25:155-163.

Bullock, Charles S., III and David J. Shafer. 1993. Party Targeting and Electoral Success. Presented at the annual meeting of the Southern Political Science Association, Savannah, November 4-6.

Canon, David T., Matthew M. Schousen and Patrick J. Sellers. 1993. The Supply-side of Congressional Redistricting: Race and Strategic Politicians, 1972-1992. Unpublished.

Dunne, John. 1994. Deposition in Georgia v. Reno, CV 194-08, S.D. GA (Augusta Division), July 5.

Ehrenhalt, Alan. 1983. Reapportionment and Redistricting. In Thomas E. Mann and Norman J. Ornstein, eds., American Elections of 1982. Washington, D.C.: American Enterprise Institute.

Hill, Kevin A. 1994. Does the Creation of Minority Access Districts Aid Republicans? An Analysis of the 1992 Congressional Elections in Eight Southern States. Presented at the Hendricks Symposium on Legislative Redistricting in the 1990s, University of Nebraska, Lincoln, April 8-9.

Holmes, Robert A. 1984. Reapportionment in Georgia. Phylon 65:179-187.

Jewell, Malcolm and David Breaux. 1995. Effects of Districting Systems on Republican Representation in Southern Legislatures. American Review of Politics 16: 1-14.

Wilde, Kathleen. 1994. Testimony in Georgia v. Reno, CV 194-08, S.D. GA (Augusta Division). 